\title{
TUTURAN KESANTUNAN IMPERATIF BAHASA INDONESIA SUKU BAJO SAMPELA
}

\section{(SPEECH POLITENESS OF INDONESIAN IMPERATIVES \\ BAJO SAMPELA ETNICH)}

\author{
Susiati \\ Universitas Iqra Buru \\ Pos-el: susiatiuniqbu@gmail.com
}

\begin{abstract}
This study aims to explain (1) SBS Indonesian imperative manners; (2) factors affecting SBS Indonesian imperative politeness.

This research is a type of qualitative research. Data were collected using observation method with moderate model moderation, record, and record technique.

The results showed that: first the SBS Indonesian imperative manifestation includes the following: (1) short length of speech; SBS's Indonesian imperative politeness in this aspect involves both, namely the speech whose number of constituents is long and the constituents are short. This is due to the mastery of Indonesian vocabulary SBS, the higher the vocabulary mastery, the longer the sentence will be told and the less mastery of vocabulary, the shorter the sentence will be told. (2) speech sequence; the highest level of SBS Indonesian imperative politeness in this aspect, ie if nonimperative information precedes its imperative speech. (3) speech intonation and kinesic cues; SBS imperative English politeness in the aspect of intonation is voiced loud, so it must be balanced with kinesik accompanying the speech. (4) the use of the expression of SBS imperative modesty in the form of imperative command, order, request, request, insistence, persuasion, appeal, madness, invitation, permission, permit, prohibition, hope, and suggestion. Secondly, the factors that affect SBS Indonesian language imperatives include social status (age, gender, and sociocultural background), power, intimacy, and indecision.

Keywords: politeness, imperative, indonesian, bajo sampela ethnic.
\end{abstract}

\begin{abstract}
Abstrak
Penelitian ini bertujuan menjelaskan (1) wujud kesantunan imperatif bahasa Indonesia SBS; (2) faktor yang memengaruhi kesantunan imperatif bahasa Indonesia SBS.

Penelitian ini merupakan jenis penelitian kualitatif. Data dikumpulkan menggunakan metode observasi dengan teknik pastisipasi model moderat, rekam, dan catat.

Hasil penelitian menunjukkan bahwa: pertama, wujud kesantunan imperatif bahasa Indonesia SBS mencakup hal-hal berikut: (1) panjang pendek tuturan; kesantunan imperatif bahasa Indonesia SBS dalam aspek ini mencakup keduanya, yakni tuturan yang jumlah konstituen katanya panjang dan konstituen katanya pendek. Hal ini disebabkan oleh penguasaan kosakata bahasa Indonesia SBS, semakin tinggi penguasaan kosakata, maka semakin panjang kalimat yang akan dituturkannya dan semakin sedikit penguasaan jumlah kosakatanya, maka semakin pendek kalimat yang akan dituturkannya. (2) urutan tutur; kadar kesantunan imperatif bahasa Indonesia SBS yang paling tinggi dalam aspek ini, yakni jika informasi nonimperatif mendahului tuturan imperatifnya. (3) intonasi tuturan dan isyarat-isyarat kinesik; kadar kesantunan imperatif bahasa Indonesia SBS dalam aspek intonasi tergolong bersuara keras, sehingga harus diimbangi dengan kinesik yang menyertai tuturan tersebut. (4) pemakaian ungkapan penanda kesantunan imperatif bahasa Indonesia SBS, yakni dalam wujud imperatif perintah, suruhan, permintaan, permohonan, desakan, bujukan, imbauan, persilaan, ajakan, izin, mengizinkan, larangan, harapan, dan anjuran. Kedua, faktor yang memengaruhi kesantunan imperatif bahasa Indonesia SBS antara lain status sosial (perbedaan umur, jenis kelamin, dan latar belakang sosiokultural), kekuasaan (power), keakraban, dan ketidaktegasan.
\end{abstract}

Kata Kunci: kesantunan, imperatif, bahasa Indonesia, suku bajo sampela. 


\section{PENDAHULUAN}

Bahasa merupakan sesuatu yang sangat fital dalam kehidupan manusia. Apalagi dalam kehidupan tersebut terjadi proses interaksi yang menghubungkan antara sesama manusia. Dalam proses interaksi sosial pelakunya selalu menggunakan alat, yakni bahasa dalam menyampaikan ide, gagasan, harapan, dan sebagainya.

Indonesia merupakan salah satu negara yang mempunyai banyak etnis yang tersebar dari Sabang sampai Merauke. Setiap kelompok etnis memiliki bahasa dan dialek masing-masing. Dalam tiap-tiap etnis, bahasa dan dialek selalu digunakan dalam berkomunikasi antarsesama masyarakat. Selain itu, dalam kelompok tersebut juga memiliki budaya dan latar belakang sosial yang berbeda dengan beragam jenis vernacular. Oleh karena itu, berbagai bahasa dan budaya tersebut harus dipertahankan untuk menjaga keberagaman dalam persatuan sebagai warisan negara Indonesia (Wacana, 2013: 34).

Di Indonesia, pada umumnya masih sering terdengar streotipe-streotipe kesukuan yang menunjukkan karakteristik pengungkapan emosi suatu budaya atau kultural tertentu dalam proses interaksi sosial. Misalnya, orang-orang Jawa dan Sunda beranggapan bahwa mereka halus dan sopan, dan orang-orang Batak kasar serta nekat, berwajah sangar dan suka berbicara dengan intonasi keras. Namun, Orang Batak sendiri menganggap bahwa mereka pemberani, terbuka, suka berterus terang. Apa yang orang Jawa dan Sunda anggap sebagai kekasaran, bagi orang Batak justru kejujuran. Apa yang orang Jawa dan Sunda anggap kehalusan, bagi orang Batak adalah kemunafikan dan kelemahan (Mulyana dalam Susiati, 2017: 5).

Susiati (2017) mengatakan bahwa dalam berinteraksi dengan suku Bajo banyak prototipe-prototipe pengalaman yang mengatakan bahwa suku Bajo itu tertutup, berbicara dengan intonasi keras, tidak sabaran, keras kepala, dan masih banyak lagi (hal. 5). Hal tersebut dipertegas oleh Suyuti (1995) yang menyatakan bahwa peluang bagi kelompok suku Bajo melakukan penolakan cukup tinggi akibat karakter budaya kelompoknya yang tertutup yang senantiasa memiliki tempat terisolasi (segregatif) dan memiliki falsafah menghindari konflik. Selain itu, suku Bajo tidak mudah percaya kepada orang asing, terlihat dari sikap suku Bajo yang membagi penempatan orang ke dalam dua kelompok, yaitu sama' dan bagai. Sama' merupakan sebutan bagi mereka yang masih termasuk dalam golongan suku Bajo (asli suku Bajo). Bagai adalah sebutan untuk mereka yang berasal di luar suku Bajo (tidak termasuk golongan asli suku Bajo) (hal. 58).

Suku Bajo merupakan suku yang bertempat tinggal di atas air laut (daerah pesisir) atau sering dijuluki rumah terapung. Suku ini banyak ditemui di Kabupaten Wakatobi. Wakatobi merupakan akronim dari empat pulau, yakni pulau Wangiwangi, Kaledupa, Tomia, dan Binongko. Dahulu nama Wakatobi adalah kepulauan Tukang Besi sekarang telah berubah nama menjadi Kabupaten Wakatobi di Provinsi Sulawesi Tenggara (Susiati, 2017: 6).

Saat ini, permukiman suku Bajo di sepanjang perairan kepulauan Wakatobi merupakan permukiman dengan jumlah populasi suku Bajo terbesar di Nusantara. Lokasi permukiman suku Bajo di Wakatobi tersebar di beberapa pulau, di antaranya Wangiwangi, Kaledupa, dan Tomia. Jumlah penduduk suku Bajo di Kabupaten Wakatobi sekitar 10.000 jiwa. Data sensus tahun 2014, suku Bajo di Wakatobi tersebar di Kecamatan Wangiwangi Selatan, yaitu di desa Mola dengan jumlah penduduknya $27,4 \%$, di Kecamatan Kaledupa, yaitu di desa Samabahari (Sampela) 
dan Mantigola jumlah penduduknya 22,6\%, di Kecamatan Kaledupa Selatan, yaitu di desa Lohoa jumlah penduduknya $12,7 \%$, di Kecamatan Tomia, yaitu di desa Lamanggau jumlah penduduknya 3,6\%.

Kemunculan penggunaan bahasa Indonesia dalam komunikasi suku Bajo dominan pada ranah-ranah publik, baik itu antarsesama suku Bajo maupun suku Bajo dengan masyarakat luar. Ranah-ranah publik yang menjadi fokus peneliti adalah di pasar dan di lingkungan masyarakat suku Bajo Sampela (SBS). Penggunaan bahasa Indonesia pada ranah-ranah tersebut dipakai sebagai perantara dalam melancarkan komunikasi dengan lawan tuturnya yang berasal dari luar SBS. Sementara, penggunaan bahasa Indonesia sesama suku Bajo pada ranah-ranah tersebut karena di mata suku Bajo penggunaan bahasa Indonesia lebih berprestise. Chaer (2012) mengatakan orang Indonesia umumnya adalah bilingual, yaitu menggunakan bahasa Indonesia dan menggunakan bahasa daerahnya. Bahasa Indonesia dominan digunakan sebagai bahasa kedua dan bahasa daerah digunakan sebagai bahasa pertama (hal. 61).

Dalam berkomunikasi baik disengaja maupun tidak disengaja selalu mempunyai tujuan. Tujuan dalam komunikasi menuntut para penuturnya untuk mencapai sesuatu yang diinginkan. Setiap kita berkomunikasi ada hal yang harus diperhatikan agar lawan bicara dapat memosisikan dirinya sesuai dengan konteks yang sedang terjadi. Pembawaan SBS saat berkomunikasi, cenderung terlihat kasar. Hal ini dipengaruhi oleh struktur bahasa daerah yang dominan mereka gunakan dalam berbahasa Indonesia.

Fenomena penggunaan bahasa Indonesia di kalangan SBS memungkinkan pula terlihatnya keunikan penggunaan kesantunan berbahasa Indonesia dalam SBS yang sering dianggap masih melanggar maksim-maksim prinsip kesantunan. Baik itu dalam kesantunan saat bertanya, memerintah, dan menginformasikan sesuatu.

Kesantunan merupakan aspek kebahasaan yang amat penting karena dapat memperlancar interaksi antarindividu. Dalam dunia sosiolinguistik, kesantunan selalu dikaitkan dengan rasa hormat, kesopanan, sikap yang baik, atau perilaku yang pantas. Dalam kehidupan sehari-hari, hubungan kesantunan dengan perilaku positif memperlihatkan bahwa kesantunan tidak hanya berhubungan dengan bahasa, tetapi juga dengan perilaku nonverbal. Hal yang menarik pula bahwa kesantunan merupakan titik temu antara bahasa dengan realitas sosial. Hal tersebut dipertegas oleh Duranti, 1997 (dalam Sailan, 2014) menyatakan bahwa fungsi bahasa sebagai alat komunikasi, mempunyai hubungan dengan masyarakat, kebudayaan, dan pikiran penuturnya, bahkan dengan dunia secara umum sehingga muncul adanya keterhubungan antara bahasa, masyarakat, budaya, dan pikiran manusia. Penggunaan kesantunan berbahasa tidak saja ditentukan oleh pilihan tuturannya, melainkan juga oleh aspek-aspek lain yang turut menentukan tingkat kesantunan, seperti usia, jarak sosial antara penutur dengan petutur, situasi, waktu, tempat, dan tujuan tuturan. Oleh karena itu, dalam pemakaian bahasa perlu memperhatikan pula konteks yang menyertainya (hal. 23).

Penelitian ini, selain merujuk pada teori-teori atau pendapat yang dikemukakan oleh para pakar, juga akan meninjau tulisan atau hasil penelitian sebelumnya yang berhubungan dengan permasalahan penelitian, sekaligus sebagai penelitian yang relevan. Hasil penelitian yang dimaksud antara lain. Nurjamily (2015), meneliti tentang Kesantunan Berbahasa Indonesia dalam Lingkungan Keluarga: Kajian Sosiopragmatik. Hasil penelitiannya menunjukkan bahwa bukan kecerdasan kognitif atau kecerdasan otak yang menjadi satu-satunya penentu keberhasilan; Gunawan (2013), meneliti tentang Wujud Kesantunan Berbahasa Mahasiswa terhadap Dosen 
di STAIN Kendari: Kajian Sosiopragmatik. Hasil penelitiannya menemukan bahwa mahasiswa STAIN Kendari dalam menyatakan kesantunannya lebih memilih menggunakan modus kalimat deklaratif dan interogatif daripada kalimat imperatif, kecuali dalam keadaan terdesak. Selain itu, penggunaan modus kalimat lengkap dan berpola urutan menjadi pilihan mahasiswa STAIN karena dianggap memiliki kadar kesantunan yang tinggi dibandingkan kalimat tidak lengkap dan berpola urutan inversi yang dianggap kurang santun; Kuntarto (2016), meneliti tentang Kesantunan Berbahasa Ditinjau dari Prespektif Kecerdasan Majemuk. Hasil penelitiannya menunjukkan bahwa kesantunan berbahasa mesti diupayakan sejak anak masih kecil, baik di rumah maupun di sekolah karena kesantunan bukan semata-mata menyangkut kemampuan berbahasa tetapi merupakan bentuk kecerdasan majemuk. Dalam realitas kehidupan tinggi IQ bukan menjadi satu-satunya faktor penentu kesuksesan.

Wahidah (2017), meneliti tentang Analisis Kesantunan Berbahasa Menurut Leech pada Tuturan Berbahasa Arab Guru Pondok Pesantren Ibnul Qoyyim Putra Yogyakarta Tahun Ajaran 2016/2017 (Kajian Pragmatik). Hasil penelitiannya menunjukkan bahwa guru mata pelajaran Tamrin Lugah Pondok Pesantren Ibnul Qoyyim Putra perlu meningkatkan prinsip kesantunan berbahasa sehingga suasana nyaman dapat tercipta dalam praktek pembelajaran di kelas. Hal ini terlihat dari hasil analisis yang membuktikan bahwa guru mata pelajaran Tamrin Lugah Pondok Pesantren Ibnul Qoyyim Putra masih sering melanggar prinsip kesantunan berbahasa atau cenderung tidak terlihat sopan.

Kesantunan imperatif dalam tiap daerah berbeda-beda. Hal ini akan terlihat pula dalam kesantunan imperatif berbahasa Indonesia. Meskipun bahasa Indonesia mempunyai kaidah-kaidah atau aturan-aturan dalam penggunaannya, tetapi tidak menutup kemungkinan pelaku bahasa dalam daerah tersebut konsisten dengan aturan-aturan yang telah ditetapkan.

Penelitian ini bertujuan mendeskripsikan wujud kesantunan imperatif berbahasa Indonesia SBS dan menjelaskan faktor yang memengaruhi kesantunan imperatif bahasa Indonesia SBS.

\section{LANDASAN TEORI}

\section{Pragmatik}

Leech (dalam Rahardi, 2005) mengatakan bahwa pragmatik merupakan bagian dari penggunaan tata bahasa (language use). Leech juga menunjukkan bahwa pragmatik dapat berintegrasi dengan tata bahasa atau gramatika yang meliputi fonologi, morfologi, dan sintaksis melalui semantik. Dalam banyak hal, gambaran yang demikian dapat dibenarkan, tetapi di dalam kenyataannya seringkali didapatkan bahwa bagian gramatika tertentu, misalnya fonologi dapat berinteraksi dengan pragmatik tanpa harus melalui semantik terlebih dahulu (hal. 2).

Banyak para pakar linguistik yang menggeluti bidang kajian pragmatik menghasilkan pemikiran-pemikiran yang dapat memberikan gambaran yang jelas tentang pragmatik. Levinson (1983), pragmatik is the study of those relations between language and context that are grammaticalized, or encoded in the structure of a language (pragmatik adalah studi bahasa yang mempelajari relasi bahasa dengan konteksnya. Konteks yang dimaksud tergramatisasi dan terkodifikasi sehingga tidak dapat dilepaskan dari struktur bahasanya) (hal. 2).

Hal yang sama diungkapkan oleh Parker (1986), pragmatik adalah cabang ilmu bahasa yang mempelajari struktur bahasa secara eksternal. Maksudnya, bagaimana 
satuan lingual tertentu digunakan dalam komunikasi yang sebenarnya. Parker pun membedakan pragmatik dengan studi seluk-beluk bahasa secara internal. Menurutnya, studi tata bahasa tidak perlu dikaitkan dengan konteks, sedangkan studi pragmatik mutlak dikaitkan dengan konteks (hal. 45).

Rahardi (2005) mengemukakan bahwa pragmatik mengkaji maksud penutur dalam menuturkan sebuah satuan lingual tertentu terhadap sebuah bahasa karena yang dikaji di dalam pragmatik adalah makna, sehingga dapat dikatakan bahwa pragmatik dalam banyak hal mempunyai kesejajaran dengan semantik yang juga mengkaji makna (hal. 1).

Dari beberapa pengertian di atas, dapat disimpulkan bahwa pragmatik adalah studi yang mempelajari tentang penggunaan dan pemaknaan suatu bahasa berdasarkan konteks yang menyertainya.

\section{Tindak Tutur}

Teori tindak tutur secara khusus telah dibahas oleh dua ahli filsafat, yaitu John Austin, 1962 dan John Searle, 1983 (dalam Sailan, 2014). Dalam formulasi keduanya menegaskan, bahasa digunakan tidak hanya menggambarkan dunia, tetapi untuk melakukan tindakan yang dapat diindikasikan dari tampilan ujaran atau tuturan itu sendiri.

Menurut Austin (1962) setidaknya terdapat tiga macam tindak tutur yang harus dipahami bersama oleh peserta tutur, yaitu:

(1) Tindak lokusioner

Tindak lokusioner atau lokusi adalah tindak berbicara dengan mengucapkan sesuatu dengan makna kata sesuai makna kamus atau makna kalimat menurut kaidah sintaksisnya.

(2) Tindak llokusioner

Tindak ilokusioner atau ilokusi adalah tindak melakukan sesuatu, yakni kita berbicara tentang maksud, fungsi, atau daya ujaran yang bersangkutan, dan bertanya untuk apa ujaran itu dilakukan.

(3) Tindak Perlokusioner

Tindak perlokusioner atau perlokusi adalah tindak tutur yang mengacu ke efek yang dihasilkan oleh penutur dengan mengatakan sesuatu (hal. 45).

\section{Solidariatas Berbahasa}

Kegiatan bertutur selalu diperhadapkan dengan topik yang ingin dikatakannya, bagaimana cara mengatakannya, serta jenis kalimat, kata, dan bunyi tertentu agar dapat selaras dengan apa yang dikatakannya. Bentuk solidaritas berbahasa dan variasi linguistik lahir dari keragaman lapisan sosial dalam masyarakat yang meliputi status sosial, ras, suku, gender, pekerjaan yang.

Bahasa sebagai bagian dari aktivitas sosial manusia dalam merefleksikan solidaritas bertujuan menghargai mitra tutur, agar lebih dekat dan berterima untuk menyatakan diri bahwa si penutur berada pada kelompok atau pada komunitas lawan bicara. Kesamaan berbahasa tidak hanya merefleksikan solidaritas sosial, tetapi juga berguna untuk memelihara solidaritas berbahasa. Jika solidaritas dikaitkan dengan kesantunan berbahasa maka konsep 'muka' menjadi gagasan utama (Nurjamily, 2015).

Menurut Brown dan Levinson (1987) ada dua jenis muka yang mengacu pada kesantunan, yaitu muka positif (positive face) dan muka negatif (negative face). Jika diamati dengan seksama, maka positive face yang menunjuk ke solidaritas bahasa, karena lebih mengutamakan penggunaan bahasa informal dan menawarkan 
pertemanan. Sementara negative face lebih pada penggunaan formalitas bahasa, mengacu pada perbedaan dan ketidaklangsungan serta menunjukkan hasrat untuk tidak diganggu dalam tindakannya (hal. 56).

Manik (dalam Sailan, 2014) menegaskan bahwa seseorang bisa melakukan solidaritas berbahasa saat berkomunikasi dengan mempertimbangkan (a) penutur yang berbahasa standar dan berbahasa daerah (bilingual), atau pengujar yang menguasai lebih dari dua bahasa (multilingual), (b) penutur yang sensitif dengan lawan bicara, (c) penutur yang menyadari register (siapa yang berbicara, kepada siapa, apa yang dibicarakan, dan dengan cara apa). Seorang penutur dapat melakukan solidaritas berbahasa bila dia mengetahui dan menyadari (a) adanya gaya bahasa diantara beda generasi (anak-anak, remaja, dewasa, orang tua, dan nenek), (b) beda posisi (status sosial), (c) beda situasi (santai, formal), (d) beda tempat (di stasiun, di kelas, di pasar, dsb) (hal. 65).

\section{Pengertian Kesantunan}

Kesantunan bersifat relatif di dalam masyarakat. Ujaran tertentu biasa dikatakan santun di dalam suatu kelompok masyarakat tertentu, akan tetapi di kelompok masyarakat lain bisa dikatakan tidak santun. Hal ini dipertegas oleh Zamzani, et al. (2010) bahwa kesantunan merupakan perilaku yang diekspresikan dengan cara yang baik atau beretika. Kesantunan merupakan fenomena kultural, sehingga apa yang dianggap santun oleh suatu kultur mungkin tidak demikian halnya dengan kultur yang lain (hal. 2).

Kesantunan mencakup intonasi. Menyatakan bahwa intonasi adalah tinggirendah suara, panjang-pendek suara, keras-lemah, jeda, dan irama yang menyertai tuturan. Intonasi dapat dibedakan menjadi dua, yakni intonasi yang menandai berakhirnya suatu kalimat atau intonasi final, dan intonasi yang berada di tengah kalimat atau intonasi nonfinal. Intonasi berfungsi untuk memperjelas maksud tuturan. Oleh karena itu, intonasi dapat dibedakan lagi menjadi intonasi berita, intonasi tanya, dan intonasi seruan. Intonasi seruan itu sendiri masih dapat diperinci lagi menjadi intonasi perintah, ajakan, permintaan, dan permohonan, Sunaryati (dalam Rahardi, 2005: 67).

\section{Teori Kesantunan Berbahasa}

Kesantunan berbahasa merupakan salah satu kajian dari ilmu pragmatik. Jika seseorang membahas mengenai kesantunan berbahasa, berarti pula membicarakan pragmatik. Tujuan kesantunan berbahasa adalah membuat suasana berinteraksi menyenangkan, tidak mengancam muka dan efektif. Beberapa pakar yang membahas kesantunan berbahasa adalah Lakoff (1972), Fraser (1978), Brown dan Levinson (1978) dan Leech (1983). Teori mereka itu pada dasarnya beranjak dari pengamatan yang sama, yaitu bahwa di dalam komunikasi yang sebenarnya, penutur tidak selalu mematuhi Prinsip Kerja Sama Grice, yang terdiri atas maksim kualitas, kuantitas, relevansi, dan cara/pelaksanaan itu. Perbedaannya antara lain terletak pada bagaimana pakar-pakar itu melihat wujud kesantunan kaidah (kaidah sosial), sedangkan Fraser serta Brown dan Levinson itu (mungkin karena yang paling mendalam), disusul oleh teori Leech.

Seperti yang di kemukakan Lakoff, Fraser, Brown dan Levinson, (dalam Gunawan, 1994: 34) Lakoff berpendapat bahwa ada tiga kaidah yang perlu kita patuhi agar ujaran kita terdengar santun oleh pendengar atau lawan bicara kita. Ketiga kaidah kesantunan itu adalah formalitas, ketangkasan, dan persamaan atau kesekawanan. Di lain sisi, Fraser membahas kesantunan bukan atas dasar kaidah, melainkan atas 
dasar strategi.

Sejalan dengan beberapa pendapat sebelumnya, Brown dan Levinson menegaskan bahwa ada tiga skala yang dapat dipakai untuk mengukur suatu kesantunan dalam masyarakat. Ketiga skala itu adalah (a) jarak sosial di antara penutur dan mitra tuturnya, (b) hubungan kekuasaan atau wewenang relatif di antara penutur dan mitra tuturnya, (c) tingkat kedudukan relatif tuturan pada situasi tertentu dengan tuturan yang sama pada situasi yang lain.

Ada beberapa strategi yang menurut Brown dan Levinson (1987: 66) dapat dipedomani dalam kesantunan negatif, antara lain sebagai berikut.

a) Strategi 1: Ungkapan secara tidak langsung

Salah satu strategi untuk menciptakan komunikasi yang santun dalam kegiatan berkomunikasi, yaitu dengan mengungkapkan secara tidak langsung. Dalam hal ini memiliki tujuan yang disampaikan si penutur tidak menyinggung atau mengancam muka si mitra tutur. Maksud yang disampaikan atau yang diinginkan si penutur walaupun diungkapkan secara tidak langsung. Misalnya, "Minta tolong eee ambilkan dulu buku itu?"

b) Strategi 2: Gunakan pagar (hedge)

Menggunakan pagar pada saat mengungkapkan maksud juga merupakan salah satu strategi untuk menciptakan komunikasi yang santun. Dengan menggunakan bentuk tuturan berpagar, kelangsungan maksud di penutur akan dapat dikurangi sehingga teras lebih santun dibandingkan dengan pengungkapan secara tidak langsung. Misalnya, "Sebenarnya dari tadi sa mau kasitau, bisa tidak sa pinjam dayung kita?"

c) Strategi 3: Bersikap pesimisme

Bersikap pesimis pada saat mengungkapkan maksud juga merupakan salah satu strategi untuk menciptakan komunikasi yang santun. Misalnya, "Saya ingin minta tolong, tetapi saya takut Bapak tidak mau"

d) Strategi 4: Meminimalkan paksaan

Salah satu strategi untuk menciptakan komunikasi yang santun, yaitu dengan tidak membebani mitra tutur atau dengan meminimalkan paksaan kepada mitra tutur. Misalnya, "maaf sa mengganggu sebentar ini?"

e) Strategi 5: Berikan penghormatan

Salah satu strategi untuk menciptakan komunikasi yang santun dalam kegiatan berkomunikasi, yaitu dengan memberikan penghormatan.

f) Strategi 6: Ungkapan permohonan maaf

Mengungkapkan permohonan maaf ketika bertutur juga merupakan salah satu strategi untuk menciptakan komunikasi yang santun. Pada umumnya mitra tutur akan merasa dihargai apabila bertutur menggunakan permohonan maaf.

g) Strategi 7: Menggunakan bentuk impersonal

Salah satu strategi untuk menciptakan komunikasi yang santun dalam kegiatan berkomunikasi, yaitu dengan tidak menyebutkan pentur dan pendengar. Misalnya, "tampaknya komputer ini perlu dipindahkan" 
h) Strategi 8: Ujaran tindak tutur itu sebagai ketentuan yang bersifat umum.

Misalnya, "penumpang tidak dibenarkan merokok di dalam bus"

Pernyataan di atas dapat disimpulkan bahwa kesantunan berbahasa adalah etika dalam berbahasa dengan tujuan untuk mencapai suasana kenyamanan dan menyenangkan antara si penutur dan si petutur.

Leech (dalam Sailan, 2014) mengajukan tujuh maksim kesantunan yang meliputi:

a) Maksim Kebijaksanaan

Dalam maksim kebijaksanaan, mengamanatkan agar penutur memberikan keuntungan atau meminimalkan kerugian bagi mitra tutur ketika berkomunikasi. Karena itu penutur harus menunjukkan keiklasan berkorban terhadap mitra tutur. Sesungguhnya maksim kebijaksanaan ini dapat dilakukan oleh siapa saja, tanpa memandang status sosial.

b) Maksim Kedermawanan

Dalam maksim kedermawanan, penutur harus rela memaksimalkan kerugian pada diri sendiri. Dalam hal ini ditunjukkan oleh penutur atas kesediaanya memberikan sesuatu yang menjadi miliknya kepada mitra tutur, agar mitra tutur menjadi tercukupi kebutuhannya.

c) Maksim Pujian

Maksim pujian ini ditunjukkan oleh kesediaan penutur pada mitra tutur untuk memberi pujian atas keberhasilan dan kelebihan mitra tutur.

d) Maksim Perendahan Hati

Maksim perendahan hati ini ditunjukkan oleh upaya penutur untuk selalu memaksimalkan ketidakhormatan pada diri sendiri, dan meminimalkan pujian pada diri sendiri serta tidak menunjukkan prestasi yang telah diraih di hadapan banyak orang ketika menjalin konteks sosial.

e) Maksim Kesetujuan

Maksim kesetujuan dicirikan oleh tercapainya kecocokan antara penutur dengan mitra tutur. Di sini sikap konfrontasi diupayakan untuk dihindari, demi menjaga keharmonisan dengan mitra tutur.

f) Maksim Kesimpatian

Maksim kesimpatian mengharuskan peserta pertuturan untuk memaksimalkan rasa simpati, dan meminimalkan rasa antipati kepada mitra tutur. Jika mitra tutur mendapatkan kesuksesan atau kebahagiaan, penutur wajib memberikan ucapan selamat. Sebalikanya jika mitra tutur mendapat kesusahan, musibah, atau cobaan penutur layak ikut berduka, atau mengutarakan bela sungkawa sebagai tanda kesimpatian.

g) Maksim Pertimbangan

Maksim pertimbangan mengharuskan penutur untuk meminimalkan rasa tidak senang pada mitra tutur, dan memaksimalkan rasa senang pada mitra tutur. Penutur berkewajiban meminta pertimbangan/saran dari mitra tutur jika ada hal-hal tertentu yang patut dipertimbangkan bersama. Biasanya dalam maksim pertimbangan dinyatakan dengan ungkapan bagaimana,... dan sebaiknya, ... (hal. 87). 


\section{Wujud Pragmatik Imperatif}

Kalimat imperatif mengandung maksud memerintah atau meminta agar mitra tutur melakukan sesuatu sebagaimana diinginkan penutur. Kalimat imperatif dalam bahasa Indonesia dapat berkisar antara suruhan yang sangat keras atau kasar sampai dengan permohonan yang sangat halus atau santun. Kalimat imperatif dapat pula berkisar antara suruhan untuk melakukan sesuatu sampai dengan larangan untuk melakukan sesuatu. Dengan demikian, dapat dikatakan bahwa kalimat imperatif dalam bahasa Indonesia itu kompleks dan banyak variasinya. Bahasa Indonesia juga membicarakan tentang wujud kesantunan imperatif. Wujud kesantunan imperatif mencakup dua macam hal, yaitu wujud formal imperatif atau struktural dan wujud pragmatik imperatif (Rahardi, 2005). Secara formal, tuturan imperatif meliputi dua macam wujud, yaitu imperatif aktif dan imperatif pasif. Wujud pragmatik imperatif adalah realisasi maksud imperatif menurut makna pragmatiknya. Makna tersebut dekat hubungannya dengan konteks situasi tutur yang melatarbelakangi munculnya tuturan imperatif itu.

Rahardi (2005) mengatakan bahwa wujud pragmatik imperatif dalam bahasa indonesia tidak selalu menjadi konstruksi imperatif. Artinya, wujud pragmatik imperatif dalam bahasa indonesia tersebut dapat berupa tuturan yang bermacammacam, dapat berupa konstruksi imperatif dan dapat pula berupa konstruksi nonimperatif (hal. 88).

Adapun yang dimaksud dengan wujud pragmatik adalah realisasi maksud imperatif dalam bahasa Indonesia apabila dikaitkan dengan konteks situasi tutur yang melatarbelakanginya. Makna pragmatik imperatif tuturan yang demikian itu sangat ditentukan oleh konteksnya. Konteks yang dimaksud dapat bersifat ekstralinguistik dan intralinguistik. Ditemukan sedikitnya tujuh belas macam makna pragmatik imperatif di dalam bahasa Indonesia dalam bentuk tuturan langsung maupun tuturan tidak langsung, yaitu (1) tuturan yang mengandung makna pragmatik imperatif perintah; (2) tuturan yang mengandung makna pragmatik imperatif suruhan; (3) tuturan yang mengandung makna pragmatik imperatif permintaan; (4) tuturan yang mengandung makna pragmatik imperatif permohonan; (5) tuturan yang mengandung makna pragmatik imperatif desakan; (6) tuturan yang mengandung makna pragmatik imperatif bujukan; (7) tuturan yang mengandung makna pragmatik imperatif imbauan; (8) tuturan yang mengandung makna pragmatik imperatif persilaan; (9) tuturan yang mengandung makna pragmatik imperatif ajakan; (10) tuturan yang mengandung makna pragmatik imperatif izin; (11) tuturan yang mengandung makna pragmatik imperatif mengizinkan; (12) tuturan yang mengandung makna pragmatik imperatif larangan; (13) tuturan yang mengandung makna pragmatik imperatif harapan; (14) tuturan yang mengandung makna pragmatik imperatif umpatan; (15) tuturan yang mengandung makna pragmatik imperatif pemberian ucapan selamat; (16) tuturan yang mengandung makna pragmatik imperatif anjuran; (17) tuturan yang mengandung makna pragmatik imperatif ngelulu (Rahardi 2005: 93).

\section{METODE PENELITIAN}

\section{Jenis Penelitian dan Pendekatan}

Penelitian ini merupakan jenis penelitian deskriptif kualitatif dengan menggunakan pendekatan pragmatik. Bogdan dan Taylor (dalam Moleong, 2007) mengemukakan bahwa jenis penelitian kualitatif merupakan salah satu prosedur 
penelitian yang menghasilkan data deskriptif berupa ucapan atau tulisan dan perilaku orang-orang yang diamati (hal. 3).

Pendekatan kualitatif diharapkan dapat menghasilkan uraian yang mendalam tentang ucapan, tulisan, atau perilaku yang dapat diamati dari suatu individu, kelompok, masyarakat, atau organisasi tertentu dalam suatu setting konteks tertentu yang dikaji dari sudut pandang yang utuh, komprehensif, dan holistik.

Penelitian deskriptif kualitatif adalah penelitian yang mengidentifikasi, mengklasifikasi, menganalisis data yang telah diperoleh, dan pendeskripsiannya berupa penggambaran bahasa sebagaimana adanya (Sudaryanto, 1993: 62). Dengan demikian, pendeskripsian data dalam penelitian ini berupa tuturan imperatif bahasa Indonesia SBS dari segi wujud atau bentuk dan faktor dengan menggunakan konsepkonsep teori yang telah dikembangkan oleh para ahli pragmatik.

\section{Sumber dan Jenis Data}

Sumber data penelitian ini adalah masyarakat SBS dengan kategori usia masa dewasa (18-25 tahun) dan masa tua (26-65 tahan). Penetapan kategori usia ini dipilih karena masih tergolong produktif dalam beraktivitas. Samarin (1993) penetapan responden antara lain memiliki alat bicara lengkap, secara psikologi memperlihatkan sikap, cerdas, dan dapat menggunakan bahasa Indonesia dengan baik (hal. 55).

Jenis data penelitian ini, yaitu data lisan berupa tuturan emosi bahasa Indonesia verbal dan nonverbal suku Bajo Sampela. Data adalah fenomena lingual khusus yang mengandung dan berkaitan langsung dengan masalah yang dimaksud (Sudaryanto, 1993: 5 ).

\section{Metode dan Teknik Pengumpulan Data}

Metode pengumpulan data dalam penelitian ini adalah metode observasi. Kartono (1980) observasi adalah studi yang disengaja dan sistematis tentang fenomena sosial dan gejala-gejala psikis dengan jalan pengamatan dan pencatatan. Observasi diarahkan pada kegiatan memperhatikan secara akurat, mencatat fenomena yang muncul, mempertimbangkan hubungan antaraspek dalam fenomena dan dilakukan dengan cara mengamati objek kajian dalam konteksnya.

Metode ini digunakan untuk mendapatkan data lisan yang disertai perilaku, yaitu berupa tuturan imperatif bahasa Indonesia suku Bajo Sampela. Teknik-teknik yang digunakan untuk melengkapi metode observasi tersebut antara lain.

\section{Teknik Observasi Partisipasi}

Melakukan kegiatan menyadap dengan berpartisipasi dalam pembicaraan, menyimak pembicaraan, dan mengamati perilaku objek yang diteliti. Observasi partisipasi (participant observation), yaitu teknik pengumpulan data yang digunakan untuk menghimpun data penelitian melalui pengamatan dan penginderaan, peneliti benar-benar terlibat dalam keseharian responden. Sibarani (2004) metode observasi partisipasi, yakni ikut berpartisipasi dalam kegiatan yang diobservasi, dideskripsi, dan dianalisis.

Jenis teknik observasi partisipasi yang digunakan dalam penelitian ini adalah partisipasi yang moderat (moderate participation). Spradley (dalam Sugiyono, 2010) mengatakan bahwa di dalam observasi partisipasi yang moderat terdapat keseimbangan antara peneliti menjadi orang dalam dan orang luar. Peneliti dalam mengumpulkan data ikut observasi partisipasi dalam beberapa kegiatan tetapi tidak semuanya. 


\section{Teknik Rekam}

Teknik ini digunakan untuk merekam peristiwa-peristiwa yang secara potensial banyak menggunakan tuturan kesantunan imperatif bahasa Indonesia SBS.

\section{Teknik Catat}

Dari hasil rekaman, data-data berupa tuturan yang diucapkan responden dicatat, selanjutnya diseleksi dan diidentifikasi berdasarkan jenis, bentuk, dan faktor penggunaan tuturan kesantunan imperatif tersebut.

\section{Teknik Analisis Data}

Pada penelitian ini, analisis data dilaksanakan bersamaan dengan proses pengumpulan data. Alur analisis mengikuti analisis data lapangan model Miles dan Huberman.

Analisis data kualitatif model Miles dan Hubermen (1984: 43) terdapat empat tahap, yaitu:

\section{Pengumpulan Data}

Data tuturan imperatif bahasa Indonesia SBS yang diperoleh dari hasil rekaman dicatat dalam catatan lapangan yang bersifat deskriptif. Catatan deskriptif adalah catatan alami, (catatan tentang apa yang dilihat, didengar, disaksikan dan dialami sendiri oleh peneliti tanpa adanya pendapat dan penafsiran dari peneliti terhadap fenomena yang dialami.

\section{Reduksi Data}

Setelah data terkumpul, selanjutnya dibuat reduksi data guna memilih data yang relevan dan bermakna, memfokuskan data yang mengarah untuk memecahkan masalah, penemuan, atau untuk menjawab pertanyaan penelitian.

Sejumlah langkah analisis selama pereduksian data penelitian ini adalah.

\section{a. Penyeleksian Data}

Tuturan imperatif bahasa Indonesia SBS yang terdapat dalam rekaman diseleksi menurut wujud atau bentuk kesantunan imperatif bahasa Indonesia SBS dan faktor yang memengaruhinya.

\section{b. Pengklasifikasian Data}

Penggolongan data hasil seleksi diidentifikasi berdasarkan pada fokus masalah yang termasuk dalam penggolongan wujud atau bentuk tuturan kesantunan imperatif bahasa Indonesia SBS dan faktornya.

\section{Penyajian Data}

Penyajian data dapat berupa bentuk tulisan atau kata-kata, gambar, grafik dan tabel. Tujuan sajian data adalah untuk menggabungkan informasi sehingga dapat menggambarkan keadaan yang terjadi.

\section{PEMBAHASAN}

\section{Wujud Linguistik Kesantunan Imperatif Bahasa Indonesia SBS}

Kesantunan linguistik imperatif bahasa Indonesia SBS mencakup hal-hal berikut:

(1) panjang pendek tuturan, (2) urutan tutur, (3) intonasi tuturan dan isyarat-isyarat kinesik, (4) pemakaian ungkapan penanda kesantunan. 


\section{a. Panjang Pendek Tuturan}

Panjang pendeknya tuturan imperatif yang digunakan dalam menyampaikan maksud kesantunan penutur itu dapat diidentifikasi dengan sangat jelas. Berikut data yang didapatkan dalam tuturan imperatif SBS. Berikut contoh tuturannya.

(1) "Ko bantu sa bawa ini kue"

(kamu bantu saya bawa ini kue)

(2) "Ko bantu bawa ini dulu kue eee"

(kamu bantu bawa ini dulu kue eee)

(3) "Ko bantu sa dulu, bawa ini kue eee!"

(kamu bantu saya dulu, bawa ini kue eee)

(4) "Ko bantu sa dulu, bawakan ini kue

eee"

(kamu bantu saya dulu, bawakan ini

kue eee)

(5) "Tabe, ko bantu sa dulu, bawakan ini

kue eee"

(tabe (permisi), kamu bantu saya

dulu, bawakan ini kue eee)

Tuturan-tuturan di atas masing-masing memiliki jumlah kata dan ukuran panjang pendek yang tidak sama, yakni secara berurutan, semakin memanjang wujud tuturannya. Tuturan (1) terdiri dari enam kata, tuturan (2) terdiri dari enam kata, tuturan (3) dan (4) berjumlah tujuh kata, tetapi pada tuturan (4) kata bawa pada tuturan (3) berubah menjadi bawakan yang berubah wujudnya daripada bentuk kata bawa. Tuturan (5) terdiri dari delapan dan merupakan tuterpanjang dari tuturantuturan imperatif sebelumnya. Dapat dikatakan bahwa dari kelima tuturan itu, tuturan (5) berkadar kesantunan paling tinggi. Tuturan (1) memiliki konotasi keras, punya kuasa, tegas, dan kasar karena adanya imperatif langsung dengan kadar penanda linguistik kesantunan yang sangat rendah sehingga ciri kelangsungan yang melekat di dalamnya sangat tinggi. Konotasi makna yang keras, punya kuasa, tegas, kasar, dan langsung berangsur-angsur semakin mengecil pada tuturan (2) karena terdapat penanda kesantunan, yakni kata dulu yang bermakna yang mula-mula (dikerjakan, diperbuat, dan sebagainya) dan interjeksi permohonan eee yang bermakna mempertegas tuturan imperatif; tuturan (3) karena terdapat penggunaan penanda linguistik, yakni kata bantu, dulu, dan interjeksi eee yang memperlihatkan kadar kesantunan imperatif. Namun, pada tuturan (4) lebih tinggi lagi kadar kesantunan imperatifnya karena kata bawa pada tuturan (3) menjadi bawakan pada tuturan (4) dengan kata bawa pada tuturan (3) menjadi bawakan pada tuturan (4), dan tuturan (5) sangat tinggi kadar kesantunan imperatifnya karena adanya penanda linguistik tabe (bahasa daerah yang bermakna permisi), bantu, dulu, bawakan, dan interjeksi eee.

Namun, perlu diketahui pula pemerolehan bahasa Indonesia dalam masyarakat SBS belum sepenuhnya maksimal sehingga masih sering temukan penggunaan tuturan imperatif dalam wujud kata atau frasa yang tergolong santun.

Konteks: Tuturan tersebut dituturkan oleh seorang ibu (A) kepada peneliti (B) yang sementara melewati jembatan rusak di lingkungan SBS.

(6) $B \quad$ :sore lbu, permisi!

A : eee pelan-pelan!

Konteks: Tuturan tersebut dituturkan oleh si A kepada si B. Si B menanyakan 
persetujuan si A untuk mengizinkan anaknya pergi ke Pulau Hoga.

(7) $B \quad$ :ikut ke Hoga besok Sela eee?

A : jangan, dia

Contoh (6) dan (7) di atas terlihat singkat konstituen kalimat si A tetapi dalam komunikasi SBS hal itu sudah mengandung kesantunan imperatif. Hal itu disebabkan karena penguasaan bahasa Indonesia belum maksimal oleh masyarakat SBS.

Dapat disimpulkan bahwa kesantunan imperatif bahasa Indonesia SBS tidak berbeda dengan kesantunan imperatif daerah-daerah lain yang sudah pernah diteliti bahwa apabila seorang penutur dapat memperpanjang tuturannya dalam bertutur dengan tidak merubah makna dasarnya, maka penutur itu akan dikatakan sebagai orang yang santun. Namun, tidak demikian berlaku sepenuhnya pada masyarakat SBS. Penggunaan pronomina orang kedua ko (kamu) dengan penunjukkan langsung kepada orang yang dituju merupakan hal yang lumrah dalam komunikasi SBS. Penunjukkan langsung dengan pronomina ko digunakan jika:

a) Si penutur lebih tua dari si petutur (petuturnya tidak mempunyai latar belakang pendidikan yang tinggi atau punya jabatan dalam suatu masyarakat dan belum berumah tangga),

b) Si penutur memiliki tingkat kesekawanan dengan si petutur (petuturnya tidak mempunyai latar belakang pendidikan yang tinggi atau punya jabatan dalam suatu masyarakat dan belum berumah tangga)

c) Jika si petutur mempunyai latar belakang seperti guru, kerja di kantor maka pronomina yang melekat padanya adalah Pak..., Ibu....

d) Jika si petutur sudah berumahtangga maka pronomina yang melekat padanya adalah "Bapak Reno"atau "Mama Reno" (Reno nama anak dari bapak/ibu tersebut)

\section{b. Urutan Tutur}

Seorang penutur akan mempertimbangkan tuturan yang digunakannya, apakah tuturannya tersebut santun atau tidak santun. Untuk dapat melihat kesantunan dalam suatu tuturan dapat melalui urutan kata. Untuk mengetahui maksud-maksud tertentu, seorang penutur biasanya mengubah urutan tuturnya agar menjadi lebih keras, tegas, santun, dan sebagainya karena urutan tutur sebuah tuturan berpengaruh besar terhadap tingkat kesantunan. Berikut contoh urutan kesantunan imperatif bahasa Indonesia SBS.

Konteks: Tuturan (7) dan (8) dituturkan oleh seorang ibu kepada seorang anak di jembatan SBS saat ibu tersebut melihat ibu (orang tua) dari anak tersebut yang sementara menjajakkan jualannya di sekitar lingkungan SBS.

(8) Kasian mama'mu itu, kasian tidak cape-cape cari uang. Ko perhatikan itu mamamu baik-baik.

(kasian mamamu itu, kasian tidak lelah mencari uang. Kamu perhatikan mamamu itu baik-baik)

(9) Ko perhatikan itu mama'mu baik-baik. Kasian mama'mu itu, kasian tidak cape-cape cari uang.

(kamu perhatikan mamamu itu baik-baik. Kasian mamamu itu, kasian tidak lelah mencari uang)

Tuturan (8) dan (9) mengandung maksud yang sama. Namun, kedua tuturan itu 
berbeda dalam hal kadar kesantunan. Urutan tutur untuk melihat kadar kesantunan imperatif bahasa Indonesia SBS tidak berbeda dengan urutan tutur pada penelitianpenelitian sebelumnya, yakni mendahulukan terlebih dahulu informasi lain yang melatarbelakangi imperatif yang dinyatakan selanjutnya. Tuturan (8) tampak lebih tinggi kadar kesantunan imperatifnya, yakni diawali kemunculan informasi "Kasian mama'mu itu, kasian tidak cape-cape cari uang." Mendahului tuturan imperatif "Ko perhatikan itu mamamu baik-baik." Tuturan yang langsung kadar kesantunannya sangat tinggi dibandingkan dengan tuturan yang tidak langsung. Tuturan (9) tampak kadar kesantunannya lebih rendah karena didahului dengan tuturan imperatif setelah itu diikuti oleh informasi yang melatarbelakanginya.

Dapat disimpulkan bahwa urutan tutur yang diawali dengan informasi nonimperatif di depannya memiliki kadar kesantunan lebih tinggi dibandingkan dengan tuturan imperatif yang mendahului informasi nonimperatinya.

\section{c. Intonasi Tuturan dan Isyarat-isyarat Kinesik}

Intonasi tuturan selalu berbeda-beda tergantung konteks yang menyertainya. SBS saat berkomunikasi terkenal dengan intonasi yang keras sehingga kebanyakan orang selalu beranggapan bahwa SBS itu berkarakter keras kepala, tidak mudah menerima saran dari orang luar. Namun, perlu diketahui bahwa dalam berkomunikasi ada aspek yang sangat menentukan apakah tuturan tersebut santun atau tidak santun, yakni kegiatan nonverbal (kinesik). Berikut ini contoh intonasi tuturan dan kinesik kesantunan imperatif bahasa indonesia SBS.

\section{Konteks:}

Tuturan (10) dituturkan dengan intonasi rendah, wajah tersenyum, tangan mengusap bahu petutur sambil mata melirik manja.

(10) Jangan dulu ko bawa!

$$
\begin{aligned}
& 2 \begin{array}{llllllll}
2 & 3 & 3 & 3 & 3 & 3 & 3 & 1
\end{array} \text { \# } \\
& \text { (jangan dulu kamu bawa) }
\end{aligned}
$$

\section{Konteks:}

Tuturan (11) dituturkan dengan intonasi keras, wajah masam, mata melotot sambil jari telunjuk menunjuk petutur.

\section{(11) Nanti salah kirim sama itu hari,}

$233333333 / / 2333$

jangan dulu ko bawa.

$\begin{array}{lllllllll}3 & 3 & 3 & 3 & 3 & 3 & 3 & 1\end{array}$

(nanti salah kirim seperti itu hari, jangan dulu kamu bawa)

Dari kedua contoh tuturan di atas, terlihat jumlah konstituen kata dalam tuturan tersebut berbeda-beda. Dari kedua tuturan di atas, jika hanya dilihat dari panjang pendeknya kalimat maka tuturan (11) dianggap lebih santun daripada tuturan (10). Padahal, jika dipertimbangkan aspek intonasi dan kinesiknya, tuturan (10)-lah yang paling sopan karena dalam konteks tuturan (10) dituturkan dengan intonasi lembut serta adanya kinesik yang menunjukkan keakraban antara si penutur dan petutur. Sementara, tuturan (11) dianggap tidak santun karena dalam konteks dituturkan dengan intonasi keras, dan kinesiknya menampakkan muka negatif kepada si 
petutur. Untuk itu, penting sekali memperhatikan aspek intonasi dan nonverbal (kinesik) dalam suatu tuturan.

\section{d. Pemakaian ungkapan penanda kesantunan}

Kesantunan dalam tuturan imperatif bahasa Indonesia SBS dapat dilihat pula dari aspek penanda linguistik. Penggunaan penanda linguistik dalam kesantunan imperatif SBS yang ditemukan hanya beberapa dari penemuan-penemuan sebelumnya. Hal ini dikarenakan penguasaan kosakata bahasa Indonesia SBS belum maksimal. Berikut tabel penanda linguistik kesantunan imperatif bahasa Indonesia SBS.

Tabel 1

\section{Penanda Linguistik Kesantunan Imperatif Bahasa Indonesia SBS}

\begin{tabular}{|c|c|c|}
\hline No & Wujud Imperatif & Penanda Linguistik \\
\hline 1 & Imperatif Perintah & sudah, mari, tabe, bisa, \\
\hline 2 & Imperatif Suruhan & kalau bisa, duluan-mi, bisa, biarlah, nanti, -mi \\
\hline 3 & Imperati Permintaan & mari dulu, dulu, mau, tabe, kalau bisa, bisakah. \\
\hline 4 & Imperatif Permohonan & mohon, hanya ingin, harap, \\
\hline 5 & Imperatif Desakan & Kalau bisa, bisa, \\
\hline 6 & Imperatif Bujukan & ini, itu, mau-mi, singgah, cantik, indah, jangan begitu. \\
\hline 7 & Imperatif Imbauan & tapi, perhatikan, sabar, agar, untuk, bagusnya, harusnya. \\
\hline 8 & Imperatif Persilaan & Mari, silakan, dulu, -mi \\
\hline 9 & Imperatif Ajakan & Kalau bisa, kalau, bisa, bagaimana \\
\hline 10 & Imperatif Permintaan Izin & bisa, minta, tabe, \\
\hline 11 & Imperatif Mengizinkan & -mi, -lah, sudah, \\
\hline 12 & Imperatif Larangan & Sebaiknya jangan, seharusnya jangan, \\
\hline 13 & Imperatif Harapan & $\begin{array}{l}\text { Harap, kalau bisa, jika bisa, mudah-mudahan, berharap, } \\
\text { harapan. }\end{array}$ \\
\hline 16 & Imperatif Anjuran & Sebaiknya, bagusnya, maunya, \\
\hline
\end{tabular}

\section{Faktor yang Memengaruhi Kesantunan Imperatif Bahasa Indonesia SBS}

Tuturan kesantunan imperatif bahasa Indonesia SBS tidak terlepas dari faktor yang memengaruhinya. Faktor-faktor yang memengaruhi kesantunan imperatif bahasa Indonesia SBS adalah

\section{a. Status Sosial}

Status sosial dalam masyarakat SBS sering menjadi faktor santun dan tidak santunnya dalam bertutur. Status sosial ditentukan oleh parameter perbedaan umur, jenis kelamin, dan latar belakang sosiokultural. 
1) Perbedaan Umur

Kesantunan imperatif bahasa Indonesia SBS tampak pada perbedaan atau kesesuaian umur antara si penutur dan si petutur. Jika si penutur lebih tua dari si petutur maka kadar kesantunannya rendah karena tuturan imperatifnya secara langsung dan jarang menggunakan penanda lingual imperatif, sedangkan jika umur si penutur lebih muda daripada si petutur, maka tingkat kesantunannya tinggi karena tuturannya secara tidak langsung dan sering menggunakan penanda lingual imperatif. Perhatikan contoh berikut.

Konteks: si A (35) menyuruh si B (17) mengangkat batu dari dalam sampan ke kolong rumah.

(12)A : sini! turun ko ke sampan, angkat itu batu bawa ke sini (ke sini! Turun kamu ke sampan, angkat sana batu bawa ke sini)

Konteks: si A (16) meminta si B (34) untuk membantunya mengangkat meja.

(13)A : : bapa'nya Rika, bisa bantu sa angkat.

(bapaknya Rika, bisa bantu

saya angkat meja ini)

2) Jenis Kelamin

Kesantunan imperatif bahasa Indonesia SBS tampak pada perbedaan jenis kelamin. Masyarakat SBS sangat menghormati dan menghargai laki-laki. Jika dalam konteks lingkungan keluarga si penutur seorang perempuan bertutur kepada laki-laki, maka kadar kesantunannya tinggi, yakni dengan menggunakan pronomina dan penanda lingual imperatif misalnya seorang istri memanggil suaminya "Bapak Reno bawakan dulu sa kayu itu". Kata Reno merupakan nama anak mereka. Namun, jika laki-laki bertutur kepada perempuan, maka kadar kesantunannya rendah karena tanpa menggunakan penanda lingual imperatif, tetapi penggunaan pronomina ada, yakni seorang suami memanggil dengan sebutan yang sama kepada sang istri "Mama Reno, mari itu kayu".

Jika dalam lingkungan masyarakat tingkat kesantunan antara laki-laki dan perempuan di SBS relatif sama. Hal ini disebabkan adanya rasa keseganan antarmereka.

3) Latar Belakang Sosiokultural

Kesantunan imperatif bahasa Indonesia SBS tampak pada latar belakang masyarakatnya. Masyarakat SBS yang berpendidikan atau yang mempunyai jabatan tertentu dalam masyarakat lebih santun daripada masyarakat biasa. Hal tersebut disebabkan pemerolehan bahasa Indonesia oleh si penutur dominan didapatkan di dunia bangku sekolah atau dalam forum-forum resmi. Masyarakat SBS sudah mengenal pendidikan terlihat adanya pendirian sekolah dan kantor-kantor pelayanan masyarakat. Contohnya.

Konteks: si A (pengajar/guru) mengajak si B (warga/tukang) melihat sampannya untuk diperbaiki.

(14)Kemarin itu anu belum begini, mungkin di kasi anu ini di rusak sama anakanak kemarin itu, bagaimana ini Bapa' mungkin Bapa' bisa perbaiki dulu! 
(kemarin ini belum begini, mungkin di kasi rusak oleh anak-anak kemarin, bagaimana ini Bapa' mungkin Bapa' bisa memperbaikinya dulu)

\section{b. Kekuasaan (Power)}

Kesantunan imperatif bahasa Indonesia SBS dipengaruhi oleh kekuasaan (power). Masyarakat SBS sangat menghormati orang-orang yang berpendidikan baik itu antarmereka maupun di luar suku mereka. Seorang kepala desa yang memiliki jabatan tertinggi memiliki peringkat kekuasaan lebih tinggi dibandingkan masyarakatnya, tetapi jika bertemu dengan seorang yang berlatar belakang pendidikan tinggi peringkat kekuasaannya merendah. Hal ini disebabkan oleh karakter budaya kelompoknya yang tertutup yang senantiasa memiliki tempat terisolasi (segregatif) dan memiliki falsafah menghindari konflik.

\section{c. Keakraban}

Kesantunan imperatif bahasa Indonesia SBS dipengaruhi oleh keakraban antara si penutur dan si petutur. Keakraban di lingkungan keluarga dan masyarakat menjadi penentu kesantunan dalam masyarakat SBS. Seberapa pun akrabnya anggota keluarga, teman, jika di dalamnya terdapat anak, adik, teman, ataupun kakak yang berpendidikan tinggi atau mempunyai jabatan (guru atau perangkat desa), maka kesantunan itu akan ada. Salah satu penanda lingual kesantunan dalam keakraban adalah pronomina, misalnya seorang kakak ingin menyuruh adiknya yang bernama Toni (seorang guru di sekolah) untuk memperbaiki posisi sampan. Kalimatnya adalah "Pak Toni, perbaikikan dulu tempat sampan itu".

\section{d. Ketidaktegasan}

Kesantunan imperatif bahasa Indonesia SBS dipengaruhi oleh ketidaktegasan antara si penutur dan si petutur. Ketidaktegasan tersebut dilakukan untuk saling menunjukkan muka positif antarpenutur dan petutur. Hal ini berlaku pula dalam kesantunan imperatif masyarakat SBS. Namun, masyarakat SBS tingkat kesantunannya tinggi dalam menerapkan ketidaktegasan jika berkomunikasi dengan orang di luar suku Bajo (bagai) daripada dengan sesama SBS (sama'). Hal ini disebabkan budaya kelompok mereka selalu berpikiran bahwa suku mereka rendah sehingga jika mereka berkomunikasi dengan orang di luar suku merupakan suatu kebanggaan tersendiri.

\section{PENUTUP}

Berdasarkan hasil pembahasan sebelumnya, dapat disimpulkan beberapa hal yang menjadi temuan dalam penelitian ini terkait wujud kesantunan imperatif bahasa Indonesia SBS dan faktor yang memengaruhi kesantunan imperatif bahasa Indonesia SBS.

Wujud kesantunan imperatif bahasa indonesia SBS mencakup hal-hal berikut: (1) panjang pendek tuturan; kesantunan imperatif bahasa Indonesia SBS dalam aspek ini mencakup keduanya, yakni tuturan yang jumlah konstituen katanya panjang dan konstituen katanya pendek. Hal ini disebabkan oleh penguasaan kosakata bahasa Indonesia SBS, semakin tinggi penguasaan kosakata, maka semakin panjang kalimat yang akan dituturkannya dan semakin sedikit penguasaan jumlah kosakatanya, maka semakin pendek kalimat yang akan dituturkannya. (2) urutan tutur; kadar kesantunan imperatif bahasa Indonesia SBS yang paling tinggi dalam aspek ini, yakni 
jika informasi nonimperatif mendahului tuturan imperatifnya. (3) intonasi tuturan dan isyarat-isyarat kinesik; kadar kesantunan imperatif bahasa Indonesia dalam aspek intonasi tergolong bersuara keras, sehingga harus diimbangi dengan kinesik yang menyertai tuturan tersebut. (4) pemakaian ungkapan penanda kesantunan imperatif bahasa Indonesia SBS, yakni dalam wujud imperatif perintah, suruhan, permintaan, rmohonan, desakan, bujukan, imbauan, persilaan, ajakan, izin, mengizinkan, larangan, harapan, dan anjuran.

Faktor yang memengaruhi kesantunan imperatif bahasa Indonesia SBS antara lain status sosial (perbedaan umur, jenis kelamin, dan latar belakang sosiokultural), kekuasaan (power), keakraban, dan ketidaktegasan.

\section{DAFTAR PUSTAKA}

Austin, J.L. (1962). How to Do Things with Words. New York: Oxford University Press. Brown, P. and S. C. Levinson. (1987). Politeness: Some universals in Language Usage. Cambridge: Cambridge University Press.

Chaer, Abdul. (2012). Linguistik Umum. Jakarta: Rineka Cipta.

Chaer, Abdul. (2010). Kesantunan Berbahasa. Jakarta: Rineka Cipta.

Gunawan, Fahmi. (2013). Wujud Kesantunan Berbahasa Mahasiswa Terhadap Dosen di STAIN Kendari (Kajian Sosiopragmatik). Journal Arbitrer, 1(1): 8-18.

Kartono, Kartini. (1980). Pengantar Metodologi Research Sosial. Bandung: Alumni.

Kuntarto, Eko. (2016). Kesantunan Berbahasa Ditinjau dari Perspektif Kecerdasan Majemuk. Jurnal IImiah Universitas Batanghari Jambi,16(2): 58-73.

Leech, Geoffrey. (1993). Principles of Pragmatics. London: Longman.

Levinson, Stephen C. (1983). Pragmatics. London: Cambridge University Press.

Miles, Matthew dan A. Michael Huberman. (1992). Analisis Contoh Kualitatif: Buku Sumber Tantang Metode-Metode Baru. Jakarta: UI Press.

Moleong, Lexy. (2007). Metodologi Penelitian Kualitatif. Bandung: Remaja Rosdakarya.

Nurjamily, Wa Ode. (2015). Kesantunan Berbahasa Indonesia dalam Lingkungan Keluarga (Kajian Sosiopragmatik). Jurnal Humanika, 3(15): 19-36.

Parker, Frank. (1986). Linguistics for Non-Linguistics. London: Little, Brown and Company Inc.

Rahardi, R Kunjana. (2005). Pragmatik Kesantunan Imperatif Bahasa Indonesia. Jakarta: Erlangga.

Sailan, Zalili. (2014). "Solidaritas dan Kesantunan Berbahasa (Telaah Pragmatik)". Dalam Pidato IImiah. Kendari.

Samarin, W.J. (1993). IImu Bahasa Lapangan (J.S Badudu, penerjemah). Yogyakarta: Kanisius.

Sibarani, Robert. (2004). Antropolinguistik: Antropologi Linguistik, Linguistik Antropologi. Medan: Poda.

Sudaryanto. (1993). Metode dan Aneka Teknik Analisis Bahasa: Pengantar Penelitian Wahana Kebudayaan secara Linguistis.Yogyakarta: Duta Wacana University Press.

Sugiyono. (2010). Memahami Penelitian Kualitatif. Bandung: CV Alfabeta.

Susiati. (2017). "Tuturan Emosi Bahasa Indonesia Verbal dan Nonverbal Suku Bajo Sampela: Kajian Psikolinguistik”. Makassar: Tesis Universitas Hasanuddin.

Suyuti, Nasruddin, dkk. (1995). "Pengkajian Sosial Budaya dan Lingkungan pada Masyarakat Bajo di Desa Sulaho Kecamatan Lasusua Kabupaten Kolaka". Kendari: Laporan Penelitian FISIP Universitas Haluoleo dan Kanwil Depsos. 
Wacana, Gitit I.P. (2013). Relasi Kekerabatan Bahasa-bahasa di Kabupaten Poso. Jurnal Kependidikan, 6(1): 19-36.

Wahidah, Yeni Lailatul dan Hendriana Wijaya. (2017). Analisis Kesantunan Berbahasa Menurut Leech pada Tuturan Berbahasa Arab Guru Pondok Pesantren Ibnul Qoyyim Putra Yogyakarta Tahun Ajaran 2016/2017 (Kajian Pragmatik). Jurnal Al Bayan, 9(1): 1-16.

Yule, George. (2006). Pragmatik. Yogyakarta: Pustaka Pelajar.

Zamzani, Tadkiroatun Musfiroh, Siti Maslakhah, Ari Listiyorini, dan Yayuk Eni Rahayu. (2010). Pengembangan Alat Ukur Kesantunan Bahasa Indonesia Dalam Interaksi Sosial Formal Bersemuka. Jurnal Penelitian Humaniora, 17(2): 1-18.

Amanto, B. S., Umanailo, M. C. B., Wulandari, R. S., Taufik, T., \& Susiati, S. (2019) Local Consumption Diversification. Int. J. Sci. Technol. Res, 8(8), 1865-1869.

lye, R., \& Susiati, S. (2018). NILAI EDUKATIF DALAM NOVEL SEBAIT CINTA DI BAWAH LANGIT KAIRO KARYA MAHMUD JAUHARI ALI (Educative Values in Sebait Cinta di Bawah Langit Kairo by Mahmud Jauhari Ali). Sirok Bastra, 6 (2), 185-191.

Susiati, S., \& lye, R. (2018). Kajian Geografi Bahasa dan Dialek di Sulawesi Tenggara: Analisis Dialektometri. Gramatika: Jurnal IImiah Kebahasaan dan Kesastraan. 6 (2), 137-151.

Susiati, S. (2018). Homonim bahasa kepulauan tukang besi dialek kaledupa di kabupaten wakatobi [the homonymon of tukang besi island languange in kaledupa dialect at wakatobi regency]. Totobuang, 6 (1), 109, 123.

Susiati, S., lye, R., \& Suherman, L. O. A. (2019). Hot Potatoes Multimedia Applications in Evaluation of Indonesian Learning In SMP Students in Buru District. ELS Journal on Interdisciplinary Studies in Humanities, 2(4), 556-570.

Susiati, S., \& lye, R. (2018). Kajian Geografi Bahasa dan Dialek di Sulawesi Tenggara: Analisis Dialektometri. Gramatika: Jurnal IImiah Kebahasaan dan Kesastraan, 6(2), 137-151.

Susiati, S., Nurhayati, N., \& Said, I. (2019). Emosi Verbal Suku Bajo Sampela. Sosial Budaya, 16(2), 114-126.

Susiati, Y. T. Risman lye. A. Kesantunan Imperatif Bahasa Indonesia Suku Bajo Sampela: Balai Pembinaan dan Pengembangan Bahasa. 2018. Kongres Bahasa Indonesia (No. 12, pp. 1-6). Report.

Susiati, S. (2020, June 2). Wujud Morfologi Bahasa Indonesia. https://doi.org/10.31219/osf.io/zsda4

Susiati, S. (2020). PENTINGNYA MELESTARIKAN BAHASA DAERAH.

Djamudi, N. L., Nurlaela, M., Nazar, A., Nuryadin, C., Musywirah, I., \& Sari, H. (2019, October). Alternative social environment policy through educational values in 
Kafi'a's customary speech to the kaledupa community of Wakatobi Island, Indonesia. In IOP Conference Series: Earth and Environmental Science (Vol. 343 , No. 1, p. 012118). IOP Publishing.

Susiati, S. PERWUJUDAN SIMILE OLEH MERARI SIREGAR DALAM NOVEL AZAB DAN SENGSARA.

Andini, K. NILAI BUDAYA SUKU BAJO SAMPELA DALAM FILM THE MIRROR NEVER LIES KARYA KAMILA ANDINI. 